\title{
Effect of Citric Acid on the Total Monomeric Anthocyanins and Antioxidant Activity of Liquor Made from Unprocessed Purple Leafed TRFK 306 Kenyan Tea Clone
}

\author{
Emily C. Kilel ${ }^{1,2 *}$, John K. Wanyoko3, Abdul K. Faraj², Peninah Ngoda ${ }^{2}$ \\ ${ }^{1}$ Department of Food Science and Nutrition, Karatina University, Karatina, Kenya \\ ${ }^{2}$ Department of Dairy and Food Science and Technology, Egerton University, Njoro, Egerton, Kenya \\ ${ }^{3}$ Kenya Agricultural Livestock Research Organization-Tea Research Institute, Kericho, Kenya \\ Email: *emilybii07@gmail.com
}

How to cite this paper: Kilel, E.C., Wanyoko, J.K., Faraj, A.K. and Ngoda, P. (2019) Effect of Citric Acid on the Total Monomeric Anthocyanins and Antioxidant Activity of Liquor Made from Unprocessed Purple Leafed TRFK 306 Kenyan Tea Clone. Food and Nutrition Sciences, 10, 1191-1201. https://doi.org/10.4236/fns.2019.1010086

Received: September 11, 2019

Accepted: October 8, 2019

Published: October 11, 2019

Copyright (๑) 2019 by author(s) and Scientific Research Publishing Inc. This work is licensed under the Creative Commons Attribution International License (CC BY 4.0).

http://creativecommons.org/licenses/by/4.0/

\begin{abstract}
A study was conducted to find out the effect of citric acid on total monomeric anthocyanins and antioxidant activity of liquor made from unprocessed purple-leafed TRFK 306 Kenyan tea, brewed at various time/temperature combinations. Most purple tea consumers usually brew the tea leaves then add some lemon juice before consuming it. Citric acid was used here to mimic the use of lemon juice. Documentation on the quality of such a brew is scanty and the effect of acid on its quality is equally scanty. The current study used brewing time/temperature combinations of 5, 10 and 15 minutes with $70^{\circ} \mathrm{C}$ and $92^{\circ} \mathrm{C}$ drinking water. Total monomeric anthocyanins were analysed using UV-1800 spectrophotometer (Shimadzu, Japan) while DDPH method was used to assay for antioxidant activity. Citric acid concentration of $0,0.1 \%$ to $0.5 \%$ was used to check their effect on the brews with the highest total anthocyanins and antioxidant activity. The results showed that brewing temperature of $70^{\circ} \mathrm{C}$ had $9.5 \mathrm{mg} / \mathrm{L}$ to $27.7 \mathrm{mg} / \mathrm{L}$, with 5 minutes brewing time being the highest. Temperature of $92^{\circ} \mathrm{C}$ had $37.5 \mathrm{mg} / \mathrm{L}$ to $92 \mathrm{mg} / \mathrm{L}$ with 5 minutes brewing time having the highest total monomeric anthocyanins. Antioxidant activity of $92^{\circ} \mathrm{C}$ brewing temperature ranged from $90.7 \%$ to $92.0 \%$. Total monomeric anthocyanins increased with increased citric acid concentration up to $0.3 \%$ before it decreases while for antioxidant activity, it decreased with addition of citric acid. It was concluded that for maximum anthocyanins extraction, 5 minutes brewing time is the best while ten minutes brewing time could give optimum antioxidant activity.
\end{abstract}




\section{Keywords}

TRFK 306, Total Monomeric Anthocyanins, Antioxidant Activity, Citric Acid, Brewing Conditions

\section{Introduction}

Tea (Camellia sinensis) (L.) O. Kuntze) has remained Kenya's leading foreign exchange earner for some years now with revenue rising to 140 billion Kenya shillings in 2018 [1]. The production has steadily been increasing over the years and it is projected to increase in the future. Tea prices are driven by supply and demand, and this calls for the tea industry to be cautious and diversifies its products especially those meant for exports. A study by Omari [2] concluded that Kenya's tea has very low product diversification and value addition compared to competitors contributing to poor performance globally [3]. Tea directorate noted that Kenya exports over $99 \%$ of her teas as black Cut, Tear and Curl (CTC), out of which $88 \%$ is exported in bulk form while the rest as value-added tea, an indication that there are limited value addition and product range. The Tea Research Institute, Kenya has developed an Assamica tea cultivar rich in anthocyanin coded TRFK 306 whose leaves have a purple appearance [4]. There are several purple leaf coloured teas which have been identified and researched in various tea growing countries [4]-[12]. The purple teas are a bred of Camellia sinensis and related tea cultivars [4] [6]. The purple-leaf tea cultivars have been studied for both the chemical composition of tissues and molecular mechanisms of colour formation. A number of studies have characterised anthocyanin contents in purple-leaf tea cultivars [6] [7] [9]). TRFK 306 is an interspecific hybrid between a tea plant (Camellia sinensis) and a brick-red pigmented non-cultivated (Camellia irrawadiensis) which is rich in anthocyanin but not suitable for processing of palatable tea products [13]. The clone has been undergoing improvement process for the last 30 years and further works on the content and antioxidant value of their anthocyanins are still in progress [13]. Special attributes of TRFK 306 include drought, frost, disease and pest resistance; high yield similar to the standard control and commercial clone TRFK 31/8; and wider adaptability [13]. The new purple clone which has been released for commercialization can be processed just like the green clones into any desired tea type and can also be utilized unprocessed. A recent study [14] found out that modification of the product either through value addition; repackaging, blending or flavouring would not have a significant influence on the competitiveness of the Kenyan tea in the global market. Optimization of brewing regimes of fresh purple-leafed teas could open alternative and cheap utilization of purple tea leaves which could be sold like fresh cut flowers. This diversification of utilization will create a wider market for this new tea variety and hence more revenue. Previously [15] proposed the need to explore alternative uses of tea in order to grow the demand for the crop. 


\section{Materials and Methods}

\subsection{Raw Materials}

Fresh TRFK 306 purple tea leaves were plucked from the fields of the Tea Research Institute (TRI). All the samples were sampled from the Timbilil Estate of TRI, Kericho $\left(0^{\circ} 22^{\prime} \mathrm{S}, 35^{\circ} 21^{\prime} \mathrm{E}\right.$, elevation of $2180 \mathrm{~m}$ above mean sea level).

\subsection{Brewing of the Liquor}

Freshly plucked youngest two leaves and a bud of purple coloured tea weighing $50 \mathrm{~g}$ were put into a $1.5 \mathrm{~L}$ thermos flask and mixed with $1000 \mathrm{~mL}$ of drinking water having varying brewing temperature of $70^{\circ} \mathrm{C} \pm 1^{\circ} \mathrm{C}, 90^{\circ} \mathrm{C} \pm 1^{\circ} \mathrm{C}$ and boiling point $\left(92^{\circ} \mathrm{C} \pm 1{ }^{\circ} \mathrm{C}\right)$. The ratio of tea leaves to boiling water used was 1:20 similar to what [16] used. For each temperature, there were three samples timed at 5 minutes, 10 minutes and 15 minutes brewing time, each in separate thermos flask. To ensure fewer temperature variations, two thermos flasks were used per experiment such that the hot water was kept in another thermos flask and brewing was done in another thermos flask. A preliminary study was done using $70^{\circ} \mathrm{C} \pm 1{ }^{\circ} \mathrm{C}, 90^{\circ} \mathrm{C}$ and boiling point $\left(92^{\circ} \mathrm{C} \pm 1^{\circ} \mathrm{C}\right)$ with the three timing durations, then later on based on the results, $70^{\circ} \mathrm{C}$ was ignored for antioxidant activity assay since we could not record significant total solids which correlate to the required volume of the sample for analysis. As for $90^{\circ} \mathrm{C}$, the results were similar to those for $92^{\circ} \mathrm{C}$ and were also ignored in both antioxidant and anthocyanin assays. For total monomeric anthocyanins, $70^{\circ} \mathrm{C}$ and $92^{\circ} \mathrm{C}$ (boiling point) were adopted. Total monomeric anthocyanins, antioxidant activity and the effect of citric acid on these two quality parameters were then determined according to the procedures described below.

\subsection{Analysis of Total Monomeric Anthocyanins}

Quantification of total monomeric anthocyanins was done using $\mathrm{pH}$ differential method [17].

\subsection{Effect of Citric Acid Concentration on Total Monomeric Anthocyanins}

This was done after getting the results of total monomeric anthocyanins using various time/temperature combinations. A 5 minute brewing time using boiling water was used for the experiment because of relatively higher total monomeric anthocyanins obtained. Once the brew was ready, food grade citric acid of 0.1, $0.2,0.3,0.4$ and $0.5 \mathrm{~g}$ were added to a $100 \mathrm{~mL}$ of the brew and determination of total monomeric anthocyanins using the protocol cited in 2.3 above was done.

\subsection{Analysis of Antioxidant Activity Using DPPH Radical Scavenging Method}

A modified method of [18] was used to assay for the antioxidant activity of the brew. 


\subsection{Effect of Citric Acid on Antioxidant Activity}

When the results of antioxidant activity had been obtained, a brew timed at ten minutes was used to check the effect citric acid concentration. Ten minutes was used since it had marginally higher percentage though not statistically significant ( $\mathrm{p}<0.05)$ from the other two timings ( 5 and 15 minutes). Once the brew was ready, food grade citric acid of $0.1,0.2,0.3,0.4$ and $0.5 \mathrm{~g}$ were added to a $100 \mathrm{~mL}$ of the brew to mimic the addition of lemon juice by the consumers. Analysis of antioxidant activity was done following the above described procedure in 2.5 to check the effect of the citric acid. Citric acid is a dominant organic acid in lemon fruits hence the choice of the acid, moreover, citric acid is also safe for human consumption [19]. Purple tea consumers usually add lemon juice to the brew from fresh purple tea leaves with sole purpose of improving its colour.

\subsection{Determination of $\mathrm{pH}$ of the Liquor}

A $\mathrm{pH}$ meter (OAKLON $\mathrm{pH} 700-\mathrm{pH} / \mathrm{Mv} / \mathrm{oC} / \mathrm{oF}$ meter) was used to measure the $\mathrm{pH}$ of each sample at room temperature and values were recorded accordingly. Determination of $\mathrm{pH}$ was necessary since addition of citric acid was expected to increase the acidity of the brew.

\section{Results and Discussion}

\subsection{Total Monomeric Anthocyanins and Antioxidant Activity by DPPH Radical Scavenging Method}

The results of total momomeric anthocyanins and antioxidant activity are presented in Table 1 . There were significant differences $(p<0.05)$ within and between time/temperature combinations. Liquor brewed at $70^{\circ} \mathrm{C}$ irrespective of the timing had less total monomeric anthocyanins than liquors brewed at boiling temperature. The highest level recorded at $70^{\circ} \mathrm{C}$ brewing temperature was 27.72 $\mathrm{mg} / \mathrm{L}$ which was lower than the lowest recorded using boiling temperature, 37.54 $\mathrm{mg} / \mathrm{L}$, though not significantly different $(\mathrm{p}<0.05)$. The highest anthocyanin levels were recorded in liquors brewed for five minutes using boiling drinking water with $92.02 \mathrm{mg} / \mathrm{L}$ and the levels decreases with increase in brewing time.

Table 1. Total monomeric anthocyanins (TA) and antioxidant activity (AA) in tea brew from unprocessed purple tea leaves.

\begin{tabular}{cccc}
\hline Temperature $\left({ }^{\circ} \mathrm{C}\right)$ & Brewing time $(\min )$. & TA $(\mathrm{mg} / \mathrm{L})$ & AA $(\%)$ \\
\hline \multirow{2}{*}{70} & 5 & $27.7^{\mathrm{cd}}$ & N/A \\
& 10 & $17.9^{\mathrm{de}}$ & N/A \\
& 15 & $9.5^{\mathrm{e}}$ & N/A \\
5 & $92.0^{\mathrm{a}}$ & $90.7^{\mathrm{a}} \pm 4.7$ \\
& 5 & $63.7^{\mathrm{bcd}}$ & $92.0^{\mathrm{a}} \pm 3.9$ \\
& 10 & $37.5^{\mathrm{cd}}$ & $91.3^{\mathrm{a}} \pm 0.9$
\end{tabular}

Means followed by the same letter (s) along the column are not significantly different at $\mathrm{p}<0.05$. $\mathrm{n}=18$. N/A means the time/temperature was not applicable in the affected row and column. 
There was no significant difference $(\mathrm{p}<0.05)$ in antioxidant activity though brewing at ten minutes showed a relatively higher antioxidant activity. The highest recorded antioxidant activity was $92.0 \%$ in liquors brewed for ten minutes using boiling water. There was a slight increase in antioxidant activity when brewed for ten minutes instead of five minutes.

The results showed that anthocyanins were detected in the liquors brewed from fresh unprocessed Kenyan purple-leafed teas. The results agree with the findings of [7]. All the samples were subjected to heat treatment using hot water thus inactivating the enzyme polyphenol oxidase inherent in tea leaves which can degrade anthocyanins [20]. The study also confirmed that anthocyanins in tea leaves can be extracted using hot water [21]. Brewing with boiling water at 5 minutes had relatively higher anthocyanins than brewing for 10 or 15 minutes. The findings corroborate the findings of [22] where they found higher anthocyanins when brewing was done between 5 and 7 minutes. Anthocyanins can also be extracted using methanol, ethanol, acetone, water or a mixture of these solvents [23]. Anthocyanins are relatively unstable pigments, and temperature is the main factor that triggers the degradation of the anthocyanins [24]. Otherwise, other factors including their chemical structure, $\mathrm{pH}$, and presence of light, ions, enzymes or oxygen can trigger their degradation [25]. Liquors brewed at $70^{\circ} \mathrm{C}$, had relatively fewer amount of anthocyanins even at 15 minutes timing compared to liquors brewed with boiling water. This could be because high extraction temperatures improve extraction efficiency. The high heat renders the cell walls more permeable facilitating extraction and increasing the solubility and diffusion coefficients of the tea components [26]. The experiment was mimicking how people currently brew unprocessed purple tea but based on the known degradation of anthocyanin at high temperatures [27], the study wanted to find out if water at $70^{\circ} \mathrm{C}$ could be sufficient. Anthocyanins levels irrespective of brewing regime, decreases with increase in time taken. The decrease in anthocyanins concentration with increase in brewing time could be because of degradation of anthocyanins with prolonged boiling which agrees with what was found by [28].

The antioxidant activity results showed that the Kenyan unprocessed purple clone has higher antioxidant potency than even some green teas found in other parts of the world displayed by [29]. In their research, they found antioxidant activity ranging from $60 \%$ to $70 \%$ lower than what this study found. The data from this study showed, there was no significant difference at $(\mathrm{p}<0.05)$ (Table 1 ), in brewing time, though 10 or 15 minutes, resulted in better liquors with higher antioxidant activity than brewing for five minutes. This could be because of better extraction of polyphenols. Total polyphenols are water soluble and have antioxidant activity [30]. There is a need for more research on this to know exactly which compounds are contributing to high antioxidant activity at 10 and 15 minutes.

\subsection{Effect of Citric Acid on Total Monomeric Anthocyanins}

The results of total monomeric anthocyanins at various acid concentrations are 
presented in Figure 1 below. The least concentration of $0.1 \mathrm{~g} / 100 \mathrm{~mL}$ citric acid had higher total monomeric anthocyanins, $103.36 \mathrm{mg} / \mathrm{L}$, than the brew without citric acid which had $92 \mathrm{mg} / \mathrm{L}$ (Figure 1 and Table 1) respectively. The content of total monomeric anthocyanins increased with increase in citric acid concentrations up to $0.3 \mathrm{~g}$ before it marginally dropped (Figure 1).

Addition of citric acid increased the content of total monomeric anthocyanins in the brew made from freshly plucked TRFK 306 tea leaves up to a concentration of $0.3 \mathrm{~g} / 100 \mathrm{~mL}$ (Figure 1 ) before it marginally decreased. The total monomeric anthocyanins increased with increasing citric acid concentration up to 0.3 g. The $\mathrm{pH}$ values also decreased from 5.3 (without citric acid) to 2.5 (with $0.5 \mathrm{~g}$ citric acid) (Table 2) with addition of citric acid. This is because the acid increased the hydrogen ion concentrations in the solution lowering $\mathrm{pH}$ values. The increase in total monomeric anthocyanins with addition of citric acid up to some point concurs with the findings of [31]. These researchers found out that presence of ascorbic acid aided to retain higher anthocyanin content than the control. They also argued that copigmentation with ascorbic acid aided to retain a higher anthocyanin content than the control. In another study by [32], they found out that addition of citric acid to Jamblang peel increased the total phenol

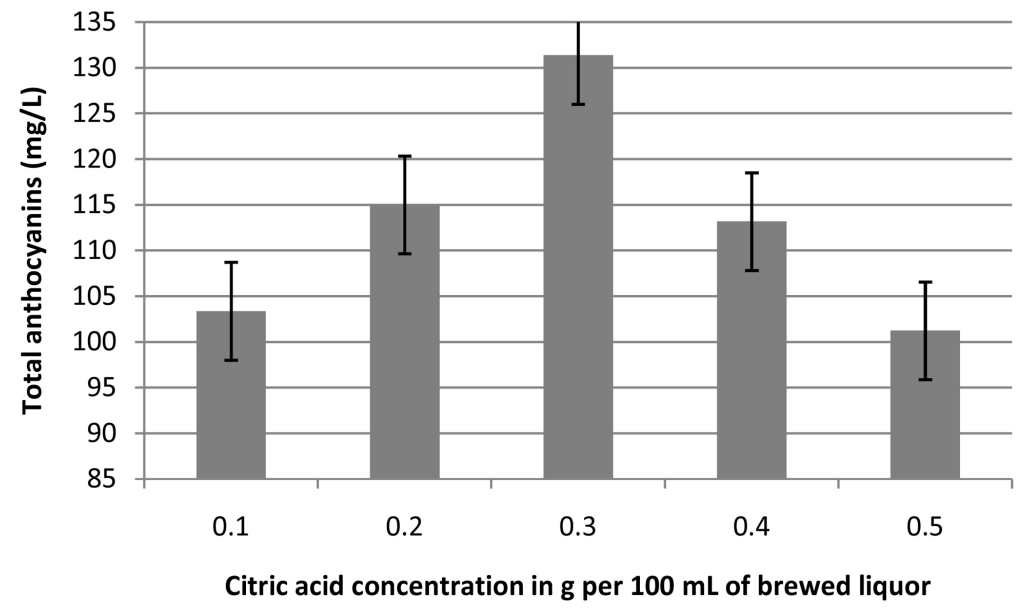

Figure 1. Effect of citric acid concentration on antioxidant activity.

Table 2. $\mathrm{pH}$ values of brew from fresh unprocessed purple-leafed teas.

\begin{tabular}{cccccc}
\hline $\begin{array}{c}\text { Time } \\
\text { (minutes) }\end{array}$ & $\begin{array}{c}\text { Citric acid } \\
\text { con. }(\mathrm{g})\end{array}$ & $\mathrm{pH}$ value & $\begin{array}{c}\text { Time } \\
\text { (minutes) }\end{array}$ & $\begin{array}{c}\text { Citric acid } \\
\text { con. }(\mathrm{g})\end{array}$ & $\mathrm{pH}$ value \\
\hline & Plain & $5.3^{\mathrm{a}} \pm 0.14$ & & Plain & $5.4^{\mathrm{a}} \pm 0.07$ \\
& 0.1 & $2.8^{\mathrm{b}} \pm 0.01$ & & 0.1 & $2.9^{\mathrm{b}} \pm 0.03$ \\
5 & 0.2 & $2.7^{\mathrm{c}} \pm 0.05$ & 0 & 0.2 & $2.6^{\mathrm{cd}} \pm 0.01$ \\
& 0.3 & $2.5^{\mathrm{de}} \pm .0 .02$ & 10 & 0.3 & $2.5^{\mathrm{de}} \pm 0.01$ \\
& 0.4 & $2.4^{\mathrm{e}} \pm 0.02$ & & 0.4 & $2.4^{\mathrm{e}} \pm 0.02$ \\
& 0.5 & $2.5^{\mathrm{e}} \pm 0.03$ & & 0.5 & $2.4^{\mathrm{e}} \pm 0.01$ \\
\hline
\end{tabular}

$\mathrm{pH}$ mean values \pm standard error are presented. Means followed by the same letter $(\mathrm{s})$ along the column are not significantly different at $\mathrm{p}<0.05 . \mathrm{n}=18$. 
and anthocyanins content of the jam in a dose dependent manner. A recent study by [33] found out that decreasing the $\mathrm{pH}$ increased the anthocyanin content in pure mulberry juice. They justified the observation by saying that structurally, anthocyanins are more stable under acidic conditions than neutral or alkaline conditions. In the current study, the results showed a decline of total monomeric anthocyanins with addition of $0.4 \mathrm{~g}$ and $0.5 \mathrm{~g}$ citric acid. This could be because more citric acid increases the release of other compounds which has the counter effect of lowering the purity of the extract and decreasing in the anthocyanin content [34].

\subsection{Effect of Citric Acid on Antioxidant Activity}

Since the results of boiling point $\left(92^{\circ} \mathrm{C}\right)$ timed at ten minutes showed higher antioxidant activity, the investigation on effect of citric acid was timed as such. The results are presented in Figure 2. The brew with no citric acid added had an antioxidant activity of $88.5 \%$ which was higher than the rest. The antioxidant activity decreases with increasing citric acid concentration where $0.5 \mathrm{~g}$ had the lowest antioxidant activity of $39.96 \%$. There was a significant difference at $(\mathrm{p}<$ $0.05)$ in the antioxidant activity at various citric acid concentrations.

Hot water was used in the current study to extract the phenolic compounds because most are soluble in water [35]. The results showed that there was a significant decrease in antioxidant activity when citric acid concentration was increased. This is so because when water is used in the extraction, like in this case, the addition of citric acid concentration decreases the antioxidant activity unlike when alcohol is used in the extraction [32] [36]. Earlier studies [37] [38] [39] explained this phenomenon by arguing that, the free form of phenolic compounds obtained from water extraction might have been destroyed by acid and hence reduction in the antioxidant activity. The results of the current study corroborate the findings of [40], who found out that addition of lemon to tea brew reduces its antioxidant activity. Citric acid is a weak organic acid that occurs naturally in various fruits and vegetables, especially citrus fruits including lemon

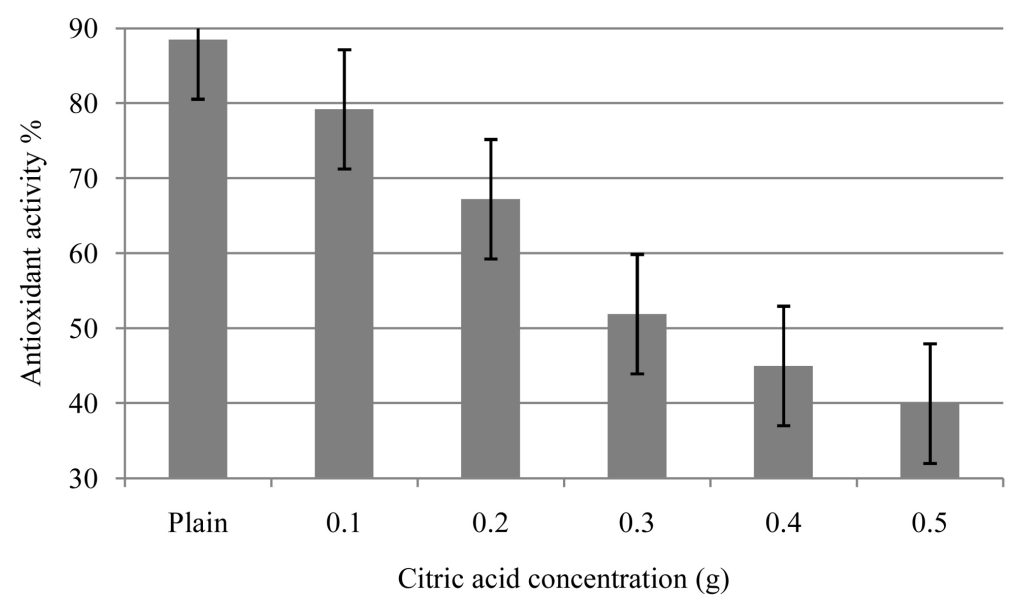

Figure 2. Effect of citric acid concentration on antioxidant activity. 
[41]. Citric acid is a secondary antioxidant that is often added to foods in combination with primary antioxidants, therefore, yielding synergistic effect to increase the activity of primary antioxidants [32] [42].

\section{4. pH Values}

The $\mathrm{pH}$ values on addition of various citric acid concentrations are depicted in Table 2. Plain liquors without citric acid added had 5.3 and $5.4 \mathrm{pH}$ values from those liquors brewed for 5 and 10 minutes, respectively. The $\mathrm{pH}$ values decrease with increase in citric acid concentration.

The $\mathrm{pH}$ values decreased with increase in citric acid addition because the acidity increased. Brew without citric acid had a $\mathrm{pH}$ of 5.3 and 5.4 while the brew with $0.5 \mathrm{~g}$ had 2.4 and 2.5 from liquors brewed for 5 and 10 minutes, respectively. The $\mathrm{pH}$ values will always increase (basic) or decrease (acidic) depending on the changes of hydrogen ions concentrations whether decreasing or increasing, respectively.

\section{Conclusion}

The finding of this study has revealed that boiling hot drinking water can be used to get liquor with high antioxidant activity timed at 10 minutes from freshly plucked unprocessed purple tea leaves and citric acid should not be added. The findings also revealed that, for maximum anthocyanins levels from unprocessed purple tea leaves, brewing using boiling drinking water timed at five minutes is the best. It is also emerging that the addition of citric acid more than $0.3 \%$ reduces the amount of anthocyanins in a brew made from fresh purple tea leaves.

\section{Acknowledgements}

The authors wish to thank the Tea Research Institute management, Kenya for facilitating this research work and allowing publication of this work.

\section{Conflicts of Interest}

The authors declare no conflicts of interest regarding the publication of this paper.

\section{References}

[1] Agriculture and Food Authority (AFA) (2018) Tea Directorate, Kenya Tea-Kenya Tea Industry Performance Highlights for December 2018.

[2] Omari, I.M. (2015) Determinants of Export Performance of Kenya Tea Development Agency Managed Factories in Kenya. Ph.D. Thesis, Jomo Kenyatta University of Agriculture and Technology, Nairobi.

[3] Atkinson, R.D. (2013) Competitiveness, Innovation and Productivity. The Information Technology and Innovation Foundation, Washington D.C., 1-4.

[4] Kamunya, S.M., Wachira, F.N., Nyabundi, K.W., Kerio, L. and Chalo, R.M. (2009) The Tea Research Foundation of Kenya Pre-Releases Purple Tea Variety for Processing 
Health Tea Product. Tea, 30, 3-10.

[5] Terahara, N., Takeda, Y., Nesumi, A. and Honda, T. (2001) Anthocyanins from Red Flower Tea (Benibama-Cha), Camellia sinensis. Phytochemistry, 56, 359-361. https://doi.org/10.1016/S0031-9422(00)00359-9

[6] Saito, T., Honma, D., Tagashira, M., Kanda, T., Nesumi, A. and Yamamoto, M.M. (2011) Anthocyanins from New Red Leaf Tea "Sunrouge". Journal of Agricultural and Food Chemistry, 59, 4779-4782. https://doi.org/10.1021/jf200250g

[7] Kerio, L.C., Wachira, F.N., Wanyoko, J.K. and Rotich, M.K. (2012) Characterization of Anthocyanins in Kenyan Teas: Extraction and Identification. Food Chemistry, 131, 31-38. https://doi.org/10.1016/j.foodchem.2011.08.005

[8] Kilel, E.C., Wanyoko, J.K., Faraj, A.K., Wachira, F.N. and Mwingirwa, V. (2013) Green Tea from Purple Leaf Coloured Tea Clones in Kenya-Their Quality Characteristics. Food Chemistry, 141, 769-775. https://doi.org/10.1016/j.foodchem.2013.03.051

[9] Joshi, R., Rana, A. and Gulati, A. (2015) Studies on Quality of Orthodox Teas Made from Anthocyanin-Rich Tea Clones Growing in Kangra Valley, India. Food Chemistry, 176, 357-366. https://doi.org/10.1016/j.foodchem.2014.12.067

[10] Lv, H.P., Dai, W.D., Tan, J.F., Guo, L., Zhu, Y. and Lin, Z. (2015) Identification of the Anthocyanins from the Purple Leaf Coloured Tea Cultivar Zijuan (Camellia sinensis var. assamica) and Characterization of Their Antioxidant Activities. Journal of Functional Foods, 17, 449-458. https://doi.org/10.1016/j.jff.2015.05.043

[11] Lai, Y.S., Li, S., Tang, Q., Li, H. X. Chen, S.X., Li, P.W., Xu, Y.O. and Guo, X. (2016) The Dark-Purple Tea Cultivar "Ziyan” Accumulates a Large Amount of Delphinidin-Related Anthocyanins. Journal of Agricultural and Food Chemistry, 64, 2719-2726. https://doi.org/10.1021/acs.jafc.5b04036

[12] Shen, J., Zou, Z., Zhang, X., Zhou, L., Wang, Y., Fang, W. and Zh, X. (2018) Metabolic Analyses Reveal Different Mechanisms of Leaf Colour Change in Two Purple-Leaf Tea Plant (Camellia sinensis L.) Cultivars. Horticulture Research, 5, 7. https://doi.org/10.1038/s41438-017-0010-1

[13] Kamunya, S.M., Wachira, F.N., Muoki, R.C. and Kinyangi, T. (2009) The Tea Research Foundation of Kenya Pre-Releases Purple Tea Variety for Processing Health Tea Product. TRFK Quarterly Bulletin, 14, 3-5.

[14] Maina, E., Mugambi, F. and Waiganjo, E. (2018) Effect of Strategic Product Development Practices on Competitiveness of Kenyan Tea in the Global Market. Business and Economics Journal, 9, 340. https://doi.org/10.4172/2151-6219.1000340

[15] Wachira, F.N., Kamunya, M.S., Kerio, L., Wanyoko, J.K., Chalo, R., Karori, S., Khalid, R., Koech, R., Ochanda, O.S., Moseti, K., Kelvin, G., Njuguna, D. and Too, C.J. (2016) Emerging Opportunities for Tea Product Diversification from Kenyan Tea Cultivars. Tea, 37, 58-69.

[16] Bhuyan, R. and Saikia, C.N. (2005) Isolation of Colour Components from Native Dye-Bearing Plants in Northeastern India. Bioresource Technology, 96, 363-372. https://doi.org/10.1016/j.biortech.2004.02.032

[17] Giusti, M.M. and Wrolstad, R.E. (2001) Characterization and Measurement of Anthocyanins by UV-Visible Spectroscopy. In: Current Protocols in Food Analytical Chemistry, John Wiley and Sons, New York, 1-13. https://doi.org/10.1002/0471142913.faf0102s00

[18] Brand-Williams, W., Cuvellier, M. and Berset, C. (1995) Use of Free Radical Method to Evaluate Antioxidant Activity. Lebensmittel-Wissenschaft \& Technologie, 28, 25-30. https://doi.org/10.1016/S0023-6438(95)80008-5 
[19] Li, Y., Han, L., Ma, R., Xu, X., Zhao, C., Wang, Z., Chen, F. and Hu, X. (2012) Effect of Energy Density and Citric Acid Concentration on Anthocyanins Yield and Solution Temperature of Grape Peel in Microwave-Assisted Extraction Process. Journal of Food Engineering, 109, 274-280. https://doi.org/10.1016/j.jfoodeng.2011.09.021

[20] Liu, L., Cao, S., Xie, B., Sun, Z. and Wu, J. (2007) Degradation of Cyanidin 3-Rutinoside in the Presence of (-)-Epicatechin and Litchi Pericarp Polyphenol Oxidase. Journal of Agricultural and Food Chemistry, 55, 9074-9078. https://doi.org/10.1021/jf071931y

[21] He, S., Lou, Q., Shi, J., Sun, H., Zhang, M. and Li, Q. (2016) Water Extraction of Anthocyanins from Black Rice and Purification Using Membrane Separation and Resin Adsorption. Journal of Food Processing and Preservation, 41, e13091. https://doi.org/10.1111/jfpp.13091

[22] Kerio, L.C., Wachira, F.N., Wanyoko, J.K. and Rotich, M.K. (2013) Total Polyphenols, Catechins Profiles and Antioxidant Activity of Tea Products from Purple Leaf Coloured Tea Cultivars. Food Chemistry, 136, 1405-1413. https://doi.org/10.1016/j.foodchem.2012.09.066

[23] Welch, C.R., Wu, Q. and Simon, J.E. (2008) Recent Advances in Anthocyanin Analysis and Characterization. Current Analytical Chemistry, 4, 75-100. https://doi.org/10.2174/157341108784587795

[24] Liazid, A., Barbero, G.F., Azarounal, L., Palma, M. and Barroso, C.G. (2014) Stability of Anthocyanins from Red Grape Skins under Pressurized Liquid Extraction and Ultrasound-Assisted Extraction Conditions. Molecules (Basel, Switzerland), 19, 21034-21043. https://doi.org/10.3390/molecules191221034

[25] Sui, X., Dong, X. and Zhou, W. (2014) Combined Effect of pH and High Temperature on the Stability and Antioxidant Capacity of Two Anthocyanins in Aqueous Solution. Food Chemistry, 163, 163-170. https://doi.org/10.1016/j.foodchem.2014.04.075

[26] Vuong, Q.V., Golding, J.B., Stathopoulo, C.E. Nguyen, M.H. and Roach, P.D. (2011) Optimizing Conditions for the Extraction of Catechins from Green Tea Using Hot Water. Journal of Separation Science, 34, 3099-3106. https://doi.org/10.1002/jssc.201000863

[27] Sharif, A., Saim N., Jasmani, H. and Ahmad, W.Y.W. (2010) Effects of Solvent and Temperature on the Extraction of Colorant from Onion (Allium cepa) Skin Using Pressurized Liquid Extraction. Asian Journal of Applied Sciences, 3, 262-268. https://doi.org/10.3923/ajaps.2010.262.268

[28] Surh, J. and Koh, E. (2014) Effects of Four Different Cooking Methods on Anthocyanins, Total Phenolics and Antioxidant Activity of Black Rice. Journal of the Science of Food and Agriculture, 94, 3296-3304. https://doi.org/10.1002/jsfa.6690

[29] Pal, S., Gosh, D., Saha, C., Chakrabarti, A.K., Datta, S.C. and Dey, S.K. (2012) Total Polyphenol Content, Antioxidant Activity and Lipid Peroxidation Inhibition Efficacy of Branded Tea (Camellia sinensis) Available in India. International Journal of Tea Science, 8, 13-20. https://www.researchgate.net/publication/235969710

[30] Serpen, A., Ebru, P., Cesarettin, A., Burçe, A.M., Havvana, T.Y., Vural, G., Nihat, Ö. and Beraat, Ö. (2012) Nutritional and Functional Characteristics of Seven Grades of Black Tea Produced in Turkey. Journal of Agricultural and Food Chemistry, 60, 7682-7689. https://doi.org/10.1021/jf302058d

[31] Brenes, C.H., Pozo-Insfran, D.D. and Talcott, S.T. (2005) Stability of Copigmented Anthocyanins and Ascorbic Acid in a Grape Juice Model System. Journal of Agricultural and Food Chemistry, 53, 49-56. https://doi.org/10.1021/jf049857w 
[32] Anggraini, T., Kurniawan, Y., Yenrina, R. and Sayuti, K. (2018) Effect of Jamblang' (Syzygium cumini) Peel and Citric Acid Addition on Antioxidant Activity of Kolang-Kaling' Jam. Pakistan Journal of Nutrition, 17, 140-145. https://doi.org/10.3923/pjn.2018.140.145

[33] Akkarachaneeyakorn, S. and Tinrat, S. (2015) Effects of Types and Amounts of Stabilizers on Physical and Sensory Characteristics of Cloudy Ready-to-Drink Mulberry Fruit Juice. Food Science and Nutrition, 3, 213-220. https://doi.org/10.1002/fsn3.206

[34] Alcazar-Alay, S.C., Cardenas-Toro, F.P., Osovio-Tobon, J.F., Barbero, G.F. and Meireles, M.A.D.A. (2017) Obtaining Anthocyanin-Rich Extracts from Frozen Acai (Euterpe oleracea Mart.) Pulp Using Pressurized Liquid Extraction. Food Science and Technology, Campinas, 37, 48-54. https://doi.org/10.1590/1678-457x.33016

[35] Yang, J. and Liu, R.H. (2012) The Phenolic Profiles and Antioxidant Activity in Different Types of Tea. International Journal of Food Science and Technology, 48, 163-171. https://doi.org/10.1111/j.1365-2621.2012.03173.x

[36] Halee, A., Supavititpatana, P., Ruttarattanamongkol, K., Jittrepotch, N., Rojsuntornkittri, K. and Kongbangkerd, T. (2018) Effects of Solvent Types and Citric Acid Concentration on the Extraction of Antioxidants from the Black Rice Bran of Oryza sativa L. cv. Hom Nin. Journal of Microbiology, Biotechnology and Food Sciences, 8, 765-769. https://doi.org/10.15414/jmbfs.2018.8.2.765-769

[37] Ammar, I., Ennouri, M. and Attia, H. (2015) Phenolic Content and Antioxidant Activity of Cactus (Opuntiaficus indica L.) Flowers Are Modified According to the Extraction Method. Industrial Crops and Products, 64, 97-104. https://doi.org/10.1016/j.indcrop.2014.11.030

[38] Bridgers, E.N., Chinn, M.S. and Truong, V.D. (2010) Extraction of Anthocyanins from Industrial Purple-Fleshed Sweet Potatoes and Enzymatic Hydrolysis of Residues for Fermentable Sugars. Industrial Crops and Products, 32, 613-620. https://doi.org/10.1016/j.indcrop.2010.07.020

[39] Rayle, D.L. and Cleland, R.E. (1992) The Acid Growth Theory of Auxin-Induced Cell Elongation Is Alive and Well. Plant Physiology, 99, 1271-1274. https://doi.org/10.1104/pp.99.4.1271

[40] Bartoszek, M., Polak, J. and Chorazewski, M. (2018) Comparison of Antioxidant Capacities of Different Types of Tea Using the Spectroscopy Methods and SemiEmpirical Mathematical Model. European Food Research and Technology, 244, 595-601. https://doi.org/10.1007/s00217-017-2986-Z

[41] Kanse, N.G., Deepali, M., Kiran, P., Priyanka, B. and Dhanke, P. (2017) A Review on Citric Acid Production and Its Applications. International Journal of Current Advanced Research, 6, 5880-5883.

https://www.researchgate.net/publication/328353869

[42] Akaranta, O. and Akaho, A.A. (2012) Synergic Effect of Citric Acid and Peanut Skin Extract on the Oxidative Stability of Vegetable Oil. Journal of Applied Sciences Environmental Management, 16, 345-351. http://www.ajol.info http://www.bioline.org.br/ja 